\title{
The Evolution of Government
}

\author{
Paul T. E. Cusack*
}

BScE, DULE, 23 Park Ave, Saint John, NB E2J 1R2, Canada

DOI: $10.36348 /$ sijlcj.2020.v03i09.006 $\quad$ | Received: 10.09.2020 | Accepted: 18.09.2020 | Published: 19.09 .2020

*Corresponding author: Paul T. E. Cusack

\section{Abstract}

When God decided to take the Hebrew people as His own, Moses was called by God to go up Mt Sinai to receive the 10 Commandments. They are the duty owed to God (No false gods; No name in vain, Keep Holy the Sabbath) and duty to self and neighbour (Honour father and mother; Do not murder; Do not commit adultery; Do not steal; Do not bear false witness; Do not covet wife; Do not covet goods.) This was the first step that God called Moses to do as He was setting up a people and their society of 12 tribes in the Holy land. That is the Divine Law. Then there is the Natural Law and Positive Law.

Keywords: Divine Law, Commandments, adultery, Holy land.

Copyright @ 2020: This is an open-access article distributed under the terms of the Creative Commons Attribution license which permits unrestricted use, distribution, and reproduction in any medium for non-commercial use (NonCommercial, or CC-BY-NC) provided the original author and source are credited.

\section{THE US CONSTITUTION HAS:}

That all men were created equal, that they are endowed by their Creator with certain unalienable Rights, that among these are Life, Liberty and pursuit of Happiness.

This could be said to be Natural Law since it comes from Nature of the human being. Positive Laws are Laws that are enacted by a legislator. Positive Law requires the enforcement by Policing. Civil Rights in the US are slow to react to the circumstances of slavery and its repercussions since 4 generations have passes. Blacks in the US still do not enjoy all the benefits of full citizenship after all these decades and protesting. John Lewis's, a civil rights activist, funeral was today as he lay in state in the US Rotunda in Washington DC.

In the same way policing is necessary to keep the civic peace between individuals within a country, a military is necessary to keep the peace outside a Nation. The US has no need to envy other countries for wealth (although that may be changing rapidly), but they do see their God given role to institute freedom around the world, until Isolationist President Donald J Trump anyway. The US has learned from past mistakes a lesson lost on Trump, that America needs free countries to trade with. The Soviet Union was all but buried since 1989 until President Vladimir Putin sought to rebuild the communist state. Putin engages in old soviet tactics of disinformation, land grabs, and spying. He has no match in Trump who naively marries on. President
Theodore Wilson said that the US must "walk softly and carry a big stick" regarding then need for the strongest military. Unfortunately, there is a need for military hand the spending that goes along with it. Most Nations allocate about $2 \%$ of their GDP on military.

War between Russia and China and the US has been resolved without a shot in the mathematics of the two-pole solution. One sine and the other cosine. Where they meet, at 45 degrees, is the maximum output. How those economies distribute the wealth is another matter.

In the community of Nations, countries have the chance of cooperating with each other in issues such as economics, health, security etc. The US for example has such agreements as NAFTA (USMCA), WHO, NATO, PPP, United Nations etc. This type of cooperation between nations is encouraging as they make citizens of the world richer, safer, healthier etc. The current US President, Donald Trump, is not in favour of such cooperation. He is a $\mathrm{n}$ isolationist. The US cannot thrive in isolation as History teaches us. Consider WW2. The US did not get involved until 1941. They must lead the world in cooperation between Nations. President I Trump is a pariah in world politics. Everyone is better off when nation states cooperate.

Are we all in it together or is it every man for himself? This is the fundamental question of political economics. Adam Smith in his Wealth of Nations writes that there is "unintended consequences of intended action." This essential justifies individualism 
at the expense of collectivism. Plato, in his Republic, the plan for a utopia in his ideal world - the forms, takes the opposite view of Smith. He has a collective solution to the necessity of humans living in community and cooperation. They must cooperate because of the division of labour. This necessitates trade and the city follows.

In another papers I wrote, I determined that this problem of collectivism vs individualism, which has been responsible for wars and the cold war is easily solved by mathematics. The optimum combination of these two extremes, collectivism, and individualism, falls into the category of the Two pole solution that has sine and cosine equal. They are equal at theta $=45$ degrees for a value of $0.7077 \times 2=1.41=$ sqrt 2 . Plato had the idea of one ideal city of which every city is a article. Interesting that the US had President Kennedy ask "Don't ask what your country can do for you; ask what you can do for your country. "This is Platonism. There will be no idea city this side of Heaven. But we can have better cities and Nations for that matter by seeing what works best. Democratic Capitalism outperforms Communism by a long shot. But individualism has little regard for the environment. Pollution is a negative externality. Why would the individual be motivated to help his neighbour? Smith assume no monopolies. This is a significant assumption. There are monopolies. That is what most for profit companies are striving to achieve.

Governments are responsible for Public Health in their nations. If we consider the public health response between the US and Canada over the recent Covid-19 pandemic, we see a glaring difference between outcomes. The US has 4.3 million cases and 146,000 deaths as of July 23020; whereas their neighbour to the North has had only 116,000 cases and only 9000 deaths. The population of the US is approximately 10 times that of Canada. Adjusted for population, Canada would have had 90,000 deaths, or only $61.6 \%$ of the US. What did Canada do right, and the US do wrong? They were consistent in their announcements at the highest levels of government. They did contract tracing; wore face coverings; and washed heir hands. Canadians also practiced social distancing. The US is in a league with Brazil and Russia.

Tax Freedom Day in the US is April $16^{\text {th }}$ in 2019; and is May $19^{\text {th }}$ in Canada. That is 105 days for the US: and 138 days for Canada or a $31.4 \%$ difference. Americans pay $29 \%$ of their income in taxes, whereas Canadians pay $37.7 \%$ for he same. Tow reason the taxes might be higher in Canada than the US is that Canadians enjoy free universal health care. The US had Obama Care, but President Trump wishes to abolish it. The second reason for higher taxes in Canada is likely because there is only $10 \%$ of the US population in Canada. It is less efficient. According to out two pole solution, with $0 \%$ tax as one pole and $100 \%$ tax at the other, the ideal tax rate is $1-0.707=29.3 \%$-essentially what the US charges its citizens. Modern governments are responsible for maintaining relatively steady economic growth - about $2 \%$ annual GDP growth. They do this by managing the Federal Reserve interest rate and the money supply. The goal is to have steady growth instead of jagged growth or decline.

It may come as a surprise that humans evolved to exist in a social group of about 150 people. We need each other when we are young; we need each other when we are sick; we need each other when we are old. Most people still today have these needs and have about 150 friends in their stable of friends. Monkeys are said to have bellicose tendencies in the wild. Perhaps there will never be a solution to the problem of war. I understand that there has never been a major global power which gave up that position without a war. Also, there has never been a weapon built that has not been used eventually. Perhaps humans have a "'war-gene" that shows itself in selfishness. The US still elects bellicose Governments and Presidents.

Education is a human right. I was fortunate enough to grow up in Canada which has a top educational system. We must distinguish between primary and secondary schooling with that of post secondary. Primary and secondary are paid for by the state with the reasoning that education results in a better society. So, society pays for that. However, post secondary can be distinguished as job training or enlightenment. The student in Canada only pays for about $20 \%$ of the cost of a university education. Still that $20 \%$ is awfully expensive. I have calculated that for every 50 minutes spent in lecture; it costs the student $\$ 5000$ CND in retirement savings from every student in that classroom. Put in those terms, university education is awfully expensive indeed. Universities are educating the workers of the future. There is also something to be said for the benefits of investing in human capital.

My education has allowed me to be able to do research (unpaid) with only a bachelors level engineering degree. However, universities do not respect the degrees granted by their own institutions even in application for graduate school. I wish I had gone the full distance to a doctorate, although the debt would have been very heavy. The biggest hurdle facing universities today is the sheer cost of proving a brick and mortar institution. Perhaps with the growth of distant online learning, a new model of education more cost effected will be evolved. Covid 19 is helping home schooling along. Given the social problems in schools in the US such as drugs and school shooting and illegitimate births, the brick and mortar school may be done. The socialization is overrated I think with problems such as bullies. Humanity, if it is to survive, must invent ways to control, if not eradicate, the bully. 
Government $s$ in the First World subsidize the Fine Arts such as Visual Arts and Performing Arts, and Literature. They also subsidize Libraries which are used by all ages, but mostly the children and the young. Governments also subsidize Museums. The Venues are a huge cost for these attractions. The goal is for the citizen to appreciate beauty. I have determined that there are laws of Beauty. See references below. Architect Le Corbusier used the ratio of the golden mean in the proportions of his designs.

Governments also subsidize Sports: Professional, Armature and the Olympics and National Games. Governments subsidize the venues, through the media coverage; and facilities such as pools and gymnasiums and exercise rooms. The goal is to instill ca competitive spirit, promote exercise and health (aside from injuries) as well as to entertain. Governments subsidize Parks and Recreation that permits walking and gardening and getting in touch with nature in an urban setting. The goal is civic pride and beautification of the environment. Subsidies to the Arts, Sports, and parks and recreation are usually first in line when budgets are constrained. People need more than just work. They need to feed the soul too. These distractions from work do that.

There are different tiers of different quality of the events depending on the population of the city. Bigger cities have more to invest in leisure activities. Because the bigger cities have a higher cost of living, citizens may not get to enjoy these activities any more than someone from say another smaller community who travels for an event.

Speaking of feeding the soul, no city would be complete without religion and the freedom of it to practice it as individuals like. In an open democracy, we live in a pluralistic society. Different religions must be tolerated. People should have freedom of conscious. Governments should not intervene in the conscience. Recall that this essay began with the Ten Commandments. It is the nature of Law to tell people what they can and cannot do morally. Its against the law to speed. Take abortion as an example. How much more so when protecting the life of the unborn. The commandment Thou Shall Not Murder is a Divine Law that dictates the conscious decision of an unwanted pregnancy. The freedom of conscience was forfeited when the intercourse took place. A moral saying is, "You can swing your arms as long as you like until you reach the end of my nose." Abortion cuts off the nose.

Whether you believe in an Afterlife or not probably depends upon whether you believe we have a soul. I have determined from my studies of the human brain that we do indeed have a soul, in fact it has an energy equation associated with it, viz. The Golden Mean Parabola. There is a Heave or Hell that is our eternal destiny. The universe is teleological and leads to
Jesus through the one universal Church. In the 1000year Messianic Era, there will be, but one Church left standing. The Covid-19 virus is punishment across the Bible belt.

Open Society involves a pluralistic democracy; a market economy; rule of Law; and diversity of opinion. Women and minorities have rights too that should be fully equal with those of white men. The US Constitution states that" All Men were created equally and endowed with certain unalienable rights by their Creator." We do not know if the drafters had in mind African Slaves and women, but of course, they should have and been clearer about it. We have already discussed the concept of the market economy vs collectivism. Tempered capitalism produces monetarily richer societies. Canadian Prime Minister Pierre Elliot Trudeau wanted to create a kinder and gentler society implied against the rugged individualism of the neighbour to the south. We have already discussed the rule of Law. The US is a very litigious society with 7 times as many lawyers as engineers compared to Japan which is the opposite ratio. We must tolerate a diversity of opinion. How dull life would be if we all looked and acted and thought the same as the Nazi's and other far right groups seemed to want.

The function of the Human soul is the golden mean parabola.

$$
\text { S.E. }=\mathrm{t}^{2}-\mathrm{t}-1
$$

Human Beings will divide in 2 whatever whole there is. Its called discrimination and at its root is Race, Language, Creed, Nationality, Age, Gender, and social Class.

So the rate of change of the division is:

$$
\begin{aligned}
& 2 t-1=1 / 2 t^{2} \\
& 4 t^{3}-2 t^{2}=1 \\
& 4 t^{3}-2 t^{2}-1=0 \\
& 4 t^{2}-2 t-1 / t=0 \\
& 1 / t=E=1 \\
& 4 t^{2}-2 t-1=0 \\
& 2\left(t^{2}-t\right)=0 \\
& t^{2}-t=0 \\
& t(t-1)=0 \\
& t=1
\end{aligned}
$$

It is therefore impossible to stop humans from dividing the whole. There is always a division to be had. The only solution is either to tolerate differences between people; or to go war incessantly. It is the job of governments to avoid wars at all costs. Therefore, toleration is the only solution.

We know from my studies in Physics that the physical universe is teleological, even though there are random events. The cycles of History have brought us to the Open Society that seems best for now. According to August Comte "social orders have moved through 
theocracy, monarchy, anarchy, and arrived at a new social order led by science" [2]. I would add that now we've entered one based on theology and science combined -Astrotheology- which will be lead by a monarch, and it will last 1000 years.

The great challenge of globalism is racism, bigotry, religious wars, economic inequality, global warming, resource depletion, pollution, etc. There are no shortages of problems in the political realm. Perhaps Plato was right: we need to have guardians who are trained to lead because thew problems are so complex. We need a Philosopher King to rule us, although monarchies were abandoned in 1789 in the beheading of Louis XVI and Marie Antoinette. God seems to prefer rule by monarch. That way He gets to choose the direction the world will go instead of the average person and his one person -one vote democracy. The meaning of life is clear to me: it is to see if we deserve Heaven or not. In the end politics should help us to get to that goal. Nothing else will matter when we die.

So, what is ahead? We are on the cusp of the 1000-year Messanic Era. The Devil will be dead; there will be no more death nor suffering, and humanity will flourish like never.

\section{REFERENCES}

1. Cusack, P. T. E. (2018). The Hebrew Civilization. $J$ of Arch and Anthro.

2. [2] Stokes, P. (2010). Philosophy 100 Essential Thinkers, Arcturus. London 2010.

3. Cusack, P. T. E. (2017). Capitalism or Socialism? Another Two-Pole Solution. J Glob Econ, 5:236.

4. Cusack, P. T. E. (2017). More on the Seven Year Economic Cycle and the Bell normal Curve. $J$ of Global Economics.

5. Cusack, P. T. E. (2016). The Fundamental Solution to Economics. Research and Reviews $J$ of Stat. and Math Sciences.
6. Cusack, P. T. E. (2017). Cusack US Economy Equation. J of Global Econ.

7. Cusack, P. T. The robust solution for epidemiology.

8. Cusack, P. T. E. (2017). The Q-B Solution. J of Global Economics, 5.

9. Cusack, P. T. E. (2017). The Sustainable Family and Political Units the Sustainable Family and Political Units. Asian Journal of Mathematical Sciences. 1(1).

10. Paul Cusack, T. E. (2015). Astro-theology: Cusack's model of the Universe. Lulu Publications. 1-629.

11. Cusack, P. T. E. (2017). Convergence of Physical Mathematics. Fluid mechanics Open Access, 4, 163.

12. Cusack, P. T. E. (2017). The Mathematical Law of Beauty in Art. AJMS, 1(1).

13. Cusack, P. T. E. (2017). The Orb: Experiential Evidence for Astrothoelogy, AJMS, 1(3).

14. Cusack, P. T. E. (2019). Golden Mean, Base "e" and the Cubit: A Puzzle. Phy Sci \& Biophy J. 3(2): 122.

15. Cusack, P. T. E. God's Circular Universe (submitted).

16. Cusack, P. T. E. Consciousness, Matter, and the Teleological Universe (submitted)

17. Cusack, P. T. E. Epistemology and Access to Truth (submitted).

18. Cusack, P. T. E. The Mathematical Law of Business., AJMS Voll no.1 2018.

19. Cusack, P. T. E. (2017). The Micro-Macro Economic Model: Stiffness and the GDP. J of Glob Econ.

20. Cusack, P. T. E. The Meaning of Life (submitted).

21. Cusack, P. T. E. Thinkers and Feelers: Jungian Psychology \& Women's' Vocation (submitted).

22. Cusack, P. T. E. Last Days before the 1000 year Messanic Era! (submitted). 